\title{
Determination of Crew Size Efficiency Relative to Urban Tree Inventories
}

\author{
Arthur H. Chappelka, Edward F. Loewenstein, Greg L. Somers, \\ Gary J. Keever, and Nicholas A. Martin
}

\begin{abstract}
Trees on the campus of Auburn University (Auburn, Alabama, U.S.) were used to test the efficiency of different crew sizes in conducting a $100 \%$ tree inventory. Seventy trees were randomly sampled at-large from a previously conducted $100 \%$ inventory (7,345 trees) on the Auburn University campus. Different crews consisting of one, two, or three individuals collected and recorded data using a GPS unit that timestamped the initiation and completion of data collection for each tree. The average time spent per tree was then calculated. Crews visited separate trees each time so there would be no overlap or bias. Each tree sampled was visited by all three crew sizes at different times. The relationship of sampling time per tree with increasing tree dbh was determined using regression analysis and subsequently likelihood ratio $\mathrm{F}$ tests. There was no statistical difference in the interval required to inventory a tree as dbh approached 0 (intercept, fixed time) for a two- and three-person crew, but the set-up (fixed) time for a one-person crew was significantly greater (approx. $2 \times$ ) irrespective of $\mathrm{dbh}$. The time interval it takes to inventory each tree increased with increasing $\mathrm{dbh}$; however, the rate of change was significantly less for a three-person crew compared with the other crew sizes. Based on these results, the number and relative sizes ( $\mathrm{dbh}$ ) of trees to be inventoried must be considered when determining optimal crew size.

Key Words. Alabama; Chinese Elm; Crew Size; i-Tree Eco; Loblolly Pine; Pinus taeda; Quercus phellos; Sampling Efficiency; Tree Inventory; Ulmus parvifolia; Urban Forest Sampling; Willow Oak.
\end{abstract}

Urban forests are ever-changing landscapes characterized by the presence of trees, other vegetation, and humans and their developments. To accurately access the urban forest and associated ecosystem services one needs to be aware of the forest's composition, health, and structure. Tree inventories are conducted and analyzed to provide this information, which then can be used for planning purposes and prioritization of tree maintenance needs (Tate 1985; Nowak et al. 2008). In conducting inventories, one important factor is resource (e.g., money, labor) availability (Massey et al. 1979; Smiley and Baker 1988). The cost to complete an inventory is determined by several aspects, including sampling area, the amount and type of data collected, and inventory personnel. The size of the crew to be used is very important in this regard. For example, is a one-person crew more efficient than a two- or three-person crew?

Nowak et al. (2008) determined that a two-person field crew using the i-Tree protocol (i-Tree 2010a; i-Tree 2010b; i-Tree 2010c) can collect data from
200, 0.04 ha plots in approximately 14 weeks. Martin et al. (2011a), as part of a larger study using a i-Tree Eco to conduct a $100 \%$ inventory on the Auburn University campus (Martin et al. 2011b), ascertained that a one-person crew was relatively more efficient than a three-person crew in data collection. A twoperson crew was found to be the most efficient based on time of data collection on a per tree basis. However, these data were collected as a small part of the overall study which was not designed to specifically test the efficiency of crew size (i-Tree 2010a; i-Tree 2010b; i-Tree 2010c). In addition, the majority of trees on the campus sampled by the one-person crew were $<25.4 \mathrm{~cm}$ in diameter. Based on these limitations, it was difficult to accurately extrapolate the data to sites with predominately larger trees.

The purpose of the current investigation was to expand on the study by Martin et al. (2011b), by determining the efficiency of crew size in urban tree inventories across a wide range of tree sizes. Urban forest inventory and sampling techniques 
and software, such as i-Tree Eco, are being used widely in the United States and other countries (Nowak et al. 2001; Escobedo et al. 2006; Escobedo 2010; Huyler et al. 2010) and can provide the resource manager with valuable information regarding urban ecosystem structure, composition, and services (Nowak and Crane 2002; Martin et al. 2012; Nowak and Greenfield 2012; Nowak et al. 2013). However, information is lacking regarding crew size efficiency of data collection.

The overall objective was to determine the time of data collection (for dbh, height, crown dimensions) using protocols developed for i-Tree Eco protocol (i-Tree 2010a; i-Tree 2010b; i-Tree $2010 \mathrm{c}$ ) on a per-tree basis and relate this to the efficiency of crew size. A university campus is an ideal location for such a study (Martin et al. 2011a). Specifically, a random number of trees were sampled by one-, two-, or three-person crews, with the time from arrival to the tree to the completion of the data sampling recorded, and then the results analyzed and compared.

\section{MATERIALS AND METHODS}

\section{Study Site and Personnel}

The study location was the Auburn University campus $\left(32^{\circ} 36^{\prime} \mathrm{N}, 85^{\circ} 30^{\prime} \mathrm{W}\right)$, Auburn, Alabama, U.S. The managed areas on the core campus comprise approximately 237 ha. The data collection occurred August 3 through October 23, 2011. An initial sample size of 90 trees was randomly selected (random numbers table) at-large from a previously conducted $100 \%$ (7,345 trees) campus inventory (Martin et al. 2011a). However, after an initial tree inspection, only 70 trees were included in the final analysis, due in part to removal or unapproachable trees resulting from ongoing construction on campus since the previous inventory (Martin et al. 2011a) was completed. To maintain consistency and remove bias in the study design, crapemyrtle (Lagerstroemia spp.) that comprised a large proportion of the initial data collection (approx. 20\%) were collected using a different protocol than the i-Tree Eco (Martin et al. 2011a) and were excluded from the current study. Diameter measurements were taken at $0.3 \mathrm{~m}$ from ground line, because the majority of trees were not measureable at breast height due to their inherent form.
Each crew was comprised of personnel with differing backgrounds, training, and experience with tree inventories and i-Tree Eco procedures. The only individual who had worked on the previous inventory (Martin et al. 2011a) was a full-time research assistant who was very familiar with the i-Tree Eco protocol, and the other two crewmembers were undergraduate students in the university's School of Forestry \& Wildlife Sciences. Before going to the field all members were trained in i-Tree Eco protocols (i-Tree 2010a; i-Tree 2010b; i-Tree 2010c). To ensure familiarity with the sampling procedures, all three individuals collected data separately and together from approx. 200 trees not included in the analysis to gain experience using i-Tree Eco procedures before commencing the efficiency study.

\section{Data Collection}

The crews were sent to separate locations (15 trees) each time in an effort to reduce any inherent bias. Each tree in the re-inventory was visited by all three crew sizes, therefore each tree was visited a total of three different times with identical measurements made on each occasion. The crews did not know which trees they would visit, the crew size, or composition of the crew until the day of data collection (i.e., the choice of the crew size to measure a particular location was arbitrary to reduce bias). The selection of members in the one- and two-person crews was random and not always uniform (same members in each crew, except the three-person crew). However, each member (one- and two-person crews) participated in approximately one-third of the sample collection.

All data were obtained following i-Tree Eco tree inventory protocol (i-Tree 2010c; Martin et al. 2011a). During the inventory, the crew (one to three individuals) collected and recorded data using a GPS (global positioning system) unit that provided a timestamp for when collection began and ended at each tree. The GPS used for the navigation as well as the data collection on each tree was a Trimble GeoXM GeoExplorer 2005 Series (Trimble Navigation Limited, Sunnyvale, California, U.S.). The tree heights and canopy measurements were made with a MDL LazerAce ${ }^{\circledast}$ Hypsometer (GeoSolution, Duluth, Georgia, U.S.). Diameter at breast height (dbh, $1.37 \mathrm{~m})$ and crown width were determined using a loggers tape. The start and stop times were recorded to the 
minute as part of the Data Dictionary (TerraSync ${ }^{\mathrm{Tm}}$ v.2.4) generated within the Trimble GeoXM. Data collected and entered into the GPS's Data Dictionary were start time, date, tree number, run number, crew initials, status, species, field land use, dbh (up to six stems), total height, height to live top, crown base, percent crown missing, crown dieback, crown light exposure, crown width (north-south), crown width (east-west), tree site, additional comments, and stop time (i-Tree 2010b; i-Tree 2010c).

\section{Statistical Analyses}

Regression analyses were employed to calculate the relationship between tree sample time and $\mathrm{dbh}$ for the three crew sizes. Likelihood ratio $F$ tests were then applied to determine whether the relationships were significantly different $(P<0.05)$ between the crew sizes by testing differences among slopes and intercepts for the crew size-dbh relationships. After removing outliers from the analysis due to crewmember error (e.g., forgot to record start and/or stop times), $\mathrm{N}=67,69,67$ trees for one-, two-, and three-person crews, respectively.

\section{RESULTS}

The trees sampled in this study included 35 species, with loblolly pine (Pinus taeda), willow oak (Quercus phellos), and Chinese elm (Ulmus parvifolia) comprising the most specimens, with 14, 7, and 5 trees, respectively. All other trees sampled contained fewer than four trees per species. Tree $\mathrm{dbh}$ ranged from $3.6-98.6 \mathrm{~cm}$ with an average of $30.5 \mathrm{~cm}$. Total height averaged $12.1 \mathrm{~m}$, with a range from $2.7-34.5 \mathrm{~m}$. Average crown spread was $7.6 \mathrm{~m}$, ranging $1.8-32.4 \mathrm{~m}$.

Likelihood ratio tests were used to compare slopes and intercepts of the three regression equa- tions (full model). In the current study, the likelihood ratio test was used in a similar manner to a comparison test in an ANOVA for discrete data. The full model would have six parameters (i.e., a slope and intercept for each crew size). Several comparisons were made (Table 1). The null hypothesis of the first test states all the slopes and all the intercepts are equal to each other; the reduced model has a single common slope and a single common intercept. The slopes and intercepts were significantly different $($ F-ratio $=50.73, P<0.0001)$; therefore, the hypothesis was rejected. Under the null hypothesis, this reduced model would have a single common slope and separate intercepts for a total of four parameters. This hypothesis was also rejected $(\mathrm{F}$-ratio $=3.54, P=0.031)$. However, when researchers used a null hypothesis of a single slope for a one- and two-person crew giving a reduced model, with two slopes and three intercepts for five parameters, the null hypothesis was not rejected, indicating it was not significantly different than the full model with six parameters (F-ratio $=1.23$, $P=0.27)$, meaning the slope for a one- and twoperson crews were not significantly different from each other. The next test used the simpler model, with four parameters as the new model and a null hypothesis of a single intercept (Table 1). The null hypothesis was rejected (F-ratio $=58.20$, $P<0.0001)$, so the intercept cannot be combined for all crew sizes. However, when only the intercepts for two- and three-person crews were combined, the null hypothesis was not rejected (F-ratio $=0.57, P=0.45)$; therefore, the intercepts were not significantly different. The simplest model (least parameters) is a model with four parameters: a common slope for the one- and two-person crews,

Table 1. Likelihood ratio tests and $P$ values comparing different models to determine differences in crew size ${ }^{2}$.

\begin{tabular}{lll}
\hline Model & Full model & Reduced model \\
\hline 1 & Independent slope and intercept for each crew size & Common slope and intercept for all crew sizes \\
2 & Independent slope and intercept for each crew size & Common slope, but independent intercepts \\
3 & Independent slope and intercept for each crew size & $\begin{array}{l}\text { One- and two-person crews with common slope, } \\
\text { but independent intercepts }\end{array}$ \\
4 & $\begin{array}{l}\text { One- and two-person crews with common slope, } \\
\text { but independent intercepts } \\
\text { One- and two-person crews with common slope, } \\
\text { but independent intercepts }\end{array}$ & $\begin{array}{l}\text { One- and two-person crews with common } \\
\text { slope and intercept }\end{array}$ \\
& $\begin{array}{l}\text { One- and two-person crews with common slope } \\
\text { and two- and three-person crew with common } \\
\text { intercept }\end{array}$
\end{tabular}

${ }^{\mathrm{z}} \mathrm{N}=67,69,67$ trees, for one-, two-, and three-person crews, respectively. 
separate slope for a three-person crew, and a separate intercept for a one-person crew, and a common intercept for two- and three-person crews (Table 1).

As shown in Figure 1, the two-and three-person crews had the same fixed time (setup) as the dbh approaches zero (intercept), but a one-person crew has a higher fixed time (approx. $2 \times$ ). The sampling times for one- and two-person crews increase at the same rate as dbh increases, but the time needed to sample a tree for a threeperson crew increased at a slower rate (Figure 1).

Using these equations (Figure 1) the relative time required to measure a tree with increasing diameters for each crew in $25.4 \mathrm{~cm}$ increments is shown in Table 2. For example, a $25 \mathrm{~cm}$ tree takes a one-person crew 4.6 minutes to measure, but a three-person crew 2.3 minutes to measure.

Table 2. Time required (minutes) to measure trees $(25.4$ cm dbh increments) by crew size.

\begin{tabular}{llcl}
\hline & \multicolumn{3}{c}{ Crew size $[\text { person }(\mathrm{s})]^{\mathrm{z}}$} \\
Diameter $(\mathrm{cm})$ & One & Two & Three \\
\hline 0 & 3.7 & 1.9 & 1.9 \\
25 & 4.6 & 2.8 & 2.3 \\
51 & 5.4 & 3.6 & 2.6 \\
76 & 6.2 & 4.4 & 3.0 \\
102 & 7.0 & 5.2 & 3.3 \\
\hline
\end{tabular}

${ }^{\mathrm{z}}$ One-person crew: Time $=3.74158+0.08265 \times \mathrm{dbh}$; two-person crew: Time $=1.94142+0.08265 \times \mathrm{dbh}$; three-person crew: Time $=1.94142+$ $0.034854 \times$ dbh. $\mathrm{N}=67,69,67$ trees, for one-, two-, and three-person crews, respectively.

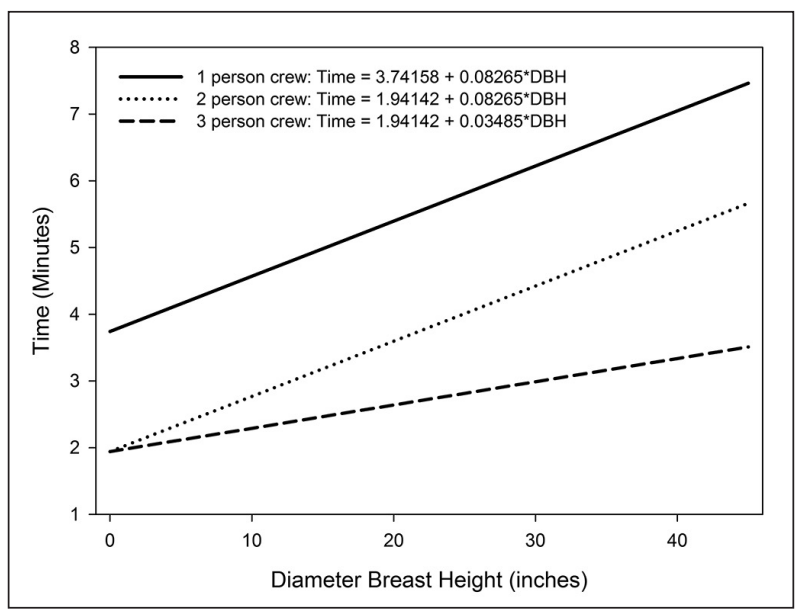

Figure 1. Sample time related to tree diameter for one-, two-, and three-person crew sizes. $\mathrm{N}=67,69,67$ trees, for one-, two-, and three-person crews, respectively.

\section{DISCUSSION}

The overall objective of this project was to evaluate crew size efficiency of a $100 \%$ inventory. In this study, researchers used the i-Tree Eco protocols, which included measuring tree dbh, height, crown characteristics, dieback, and percent missing crown. However, the results are applicable to the vast majority of other tree inventories. Based on the results there was a higher fixed time (setup) spent by the one-person crew than the others, irrespective of tree dbh. It took 3.7 minutes for setup (fixed time) for the one-person crew compared to 1.9 minutes for the other crews. These times may vary depending on the experience of the crews conducting the surveys, and on the site characteristics (e.g., topography). It stands to reason that it would take a oneperson crew a longer time to setup the equipment than a larger crew size as reflected by the analysis. However, once this task was completed the rate of change (slopes) as dbh increased was the same for one- and two-person crews and increased at a slower rate for the three-person crew. Therefore, there was a time-saving per increasing dbh using a threeperson crew. These results can be very helpful for managers who want to conduct tree inventories.

The number of trees (and their relative sizes) play a major role in deciding the crew size. To illustrate this point, three hypothetical examples are included. The time to complete these tasks was estimated using the equations illustrated in Figure 1 and Table 2. First 100, $2.54 \mathrm{~cm}$ trees were to be inventoried. The time to complete the inventory was $6.4,3.4$, and 3.3 hours for one-, two-, and three-person crews, respectively. The cost was USD $\$ 64, \$ 68$, and $\$ 99$ for one-, two-, and three-person crews, respectively, at $\$ 10 /$ hour per crewmember. Based on this cost alone a one- or two-person crew would be the most efficient. However, travel time, food, lodging (if traveling overnight), and fuel for a vehicle or vehicles, among other expenses, will influence the cost depending on the number of crewmembers, and need to be included in a total estimate.

Second, for a manager with 1,000 trees to inventory with an average diameter of $25.4 \mathrm{~cm}$, a oneperson crew would require 77 hours, a two-person crew 47 hours, and a three-person crew 38 hours to complete the inventory. This would represent a saving of 30 and 39 hours, respectively, for the two- and 
three-person crews relative to a one-person crew. If each member was paid $\$ 10 /$ hour, the cost, excluding travel time and other such expenditures, would be $\$ 770, \$ 940$, and $\$ 1,140$ for a one-, two-, or threeperson crew, respectively. Based solely on \$/crew, the one-person crew would be more efficient, saving the manager $\$ 170$ or $\$ 370$ depending on if the crew size were two or three persons. However, they would spend approx. 1.7 to $2 \times$ more time conducting the inventory compared with the two- and three-person crews, respectively. The manager needs to consider time as a factor in his or her determinations.

Finally, as an extreme comparison, perhaps a manager plans to inventory 10,000 trees averaging $101.6 \mathrm{~cm}$ dbh. If each crewmember was paid $\$ 10$ / hour, the cost excluding travel time and other associated costs, would be $\$ 11,670, \$ 17,340$, and $\$ 16,500$ for a one-, two-, or three-person crew, respectively. Based solely on \$/crew, the one-person crew would be more efficient, saving the manager $\$ 5,670$ or $\$ 4,830$ depending on whether the crew size were two or three persons. However, if time were factored in, the one-person crew would spend approx. $1.3 \times$ to $2.1 \times$ longer in the field compared with the other crews, using a 40-hour week as a metric. A one-person crew would require 1,167 hours, or approximately 29 weeks to complete the task. A two-person or three-person crew would spend 867 hours (approx. 22 weeks) and 550 hours (approx. 14 weeks), respectively, to complete the inventory. This would represent a saving of 300 and 617 hours, or 7.5 and 15.4 weeks, respectively, for the two- and three-person crews relative to a one-person crew. Overall, the three-person crew could be considered the most efficient based on time in this case. The job did cost more to conduct, approx. $\$ 5,000$ more than the one-person crew, but $\$ 1,000$ less than a two-person crew. However, the crew would spend considerably less time in the field than the other crews, thus allowing them to do other tasks compared with the other crews.

In addition, the training of the crews may be an important consideration in deciding crew size. The larger the crew, the probability that one member may not be as well-trained increases. This would probably increase the time spent per tree initially. However, after training, having more than one well-trained person is an advantage in the event of illness or other reasons for lack of crewmem- ber availability. Also, the safety of the worker is an important consideration. Having more than one individual on a crew may be beneficial, especially if working in more remote locations.

\section{CONCLUSION}

The primary intent of the study was to test the efficiency in crew size in conducting a 100\% inventory using i-Tree Eco protocol. The data showed interesting trends in crew size and productivity. These data can be very helpful for managers who want to conduct $100 \%$ tree inventories. Among all factors to be considered (e.g., location, distance of travel, types of trees to be measured, worker safety), the number and size of trees to be inventoried will play a major part in deciding the ideal crew size to use.

The data tend to support Martin et al. (2011b) and Nowak et al. (2008), in general, in that a twoperson crew may be the best utilization of time and effort for a $100 \%$ inventory. However, a manager may wish to use a three-person crew if very large trees are being measured, or if the total time available to complete the inventory is limited and resources (e.g., equipment, money) are less restrictive. If time is not a restriction, a one-person crew may be the most efficient regarding the funds spent.

Acknowledgments. We would like to thank Dudley Hartel and Eric Kuehler of the USDA Forest Service-Urban Forestry South office (Athens, Georgia, U.S.) for their assistance and guidance during the duration of this project. We would also like to thank Andrew Metzler, Alex Hedgepath, and Efrem Robbins for their assistance with data collection, and James Ransom and Ann Huyler for their technical assistance. This project was funded in part by Auburn University and the USDA Forest Service Co-op Agreement FS-SRS09-CA-11330144-073.

\section{LITERATURE CITED}

Escobedo, F., S. Varela, M. Zhao, J.E. Wagner, and W. Zipperer. 2010. Analyzing the efficacy of subtropical urban forests in offsetting carbon emissions from cities. Environmental Science \& Policy 13:362-372.

Escobedo, F.J., D.J. Nowak, J.E. Wagner, C.L. De la Maza, M. Rodriguez, D.E. Crane, and J. Hernandez. 2006. The socioeconomics and management of Santiago de Chile's public urban forests. Urban Forestry \& Urban Greening 4:105-114.

Huyler, A., A.H. Chappelka, and E.F. Loewenstein. 2010. UFORE Model Analysis of the Structure and Function of the Urban Forest in Auburn, Alabama. pp. 18-23. In: Emerging Issues Along Urban-Rural Interfaces III: Linking Science and Society Conference Proceedings, Atlanta, Georgia, U.S., April 11-14, 2010.

i-Tree. 2010a. i-Tree: Tools for Assessing and Managing Community Forests. <www.itreetools.org> 
i-Tree. 2010b. i-Tree Software Suite v4.0 User's Manual. <www. itreetools.org/resources/manuals/i-Tree Eco Users Manual.pdf>

i-Tree.2010c. UFOREMethods. <www.itreetools.org/eco/resources/ UFORE\%20Model\%20FAQs.pdf>

Martin, N.A, A.H. Chappelka, G.J. Keever, and E.F. Loewenstein. 2011a. A 100\% tree inventory using i-Tree Eco protocol: A case study at Auburn University, Alabama. Arboriculture \& Urban Forestry 37:207-212.

Martin, N.A., A.H. Chappelka, E.F. Loewenstein, and G.J. Keever. 2011b. Optimum urban tree inventory crew size: Results from an i-Tree Eco project at Auburn University. City Trees 47(6):16.

Martin, N.A., A.H. Chappelka, E.F. Loewenstein, and G.J. Keever. 2012. Comparison of carbon storage, carbon sequestration, and air pollution removal by protected and maintained urban forests in Alabama, USA. International Journal of Biodiversity Science, Ecosystem Services and Management 8:265-272.

Massey, J.G., W.K. Murphey and R. S. Dewers. 1979. The economics of urban tree inventory systems: Fort Worth, a case study. Journal of Arboriculture 5(10):233-235.

Nowak, D.J., and D.E. Crane. 2002. Carbon storage and sequestration by urban trees in the United States. Environmental Pollution 116(3):381-389.

Nowak, D.J., and E.J. Greenfield. 2012. Tree and impervious cover change in U.S. cities. Urban Forestry \& Urban Greening 11:21-30.

Nowak, D.J., J.T. Walton, J.C. Stevens, D.E. Crane, and R.E. Hoehn. 2008. Effect of plot and sample size on timing and precision of urban forest assessments. Arboriculture \& Urban Forestry 34:386-390.

Nowak, D.J., M.H. Noble, S.M. Sisinni, and J.F. Dwyer. 2001. People and trees: Assessing the U.S. urban forest resource. Journal of Forestry 99:37-42.

Nowak, D.J., S. Hirabayashi, A. Bodine, and R. Hoehn. 2013. Modeled PM2.5 removal by trees in tem U.S. cities and associated health effects. Environmental Pollution 178:395-402.

Smiley, T.E., and F.A. Baker. 1988. Options in street tree inventories. Journal of Arboriculture 14(2):36-42.

Tate, R.L. 1985. Uses of street tree inventory data. Journal of Arboriculture 11(7):210-213.
Arthur H. Chappelka (corresponding author)

School of Forestry and Wildlife Sciences

Auburn University

Auburn, Alabama 36849, U.S.

e-mail: chappah@auburn.edu

phone: 1-334-332-1047

fax: 1-334-332-1084

Edward F. Loewenstein

School of Forestry and Wildlife Sciences

Auburn University

Auburn, Alabama 36849, U.S.

loeweed@auburn.edu

Greg L. Somers

School of Forestry and Wildlife Sciences

Auburn University

Auburn, Alabama 36849, U.S.

somergl@auburn.edu

Gary J. Keever

Department of Horticulture

Auburn University

Auburn, Alabama 36849, U.S.

keevegj@auburn.edu

Nicholas A. Martin

Assistant Manager

Bartlett Inventory Solutions

Bartlett Tree Research Laboratories

13768 Hamilton Road

Charlotte, North Carolina 28278, U.S.

nmartin@bartlett.com 
Résumé. Les arbres du campus de l'Université d'Auburn (Auburn, Alabama, États-Unis) ont été utilisés pour tester l'efficacité d'équipes comportant un nombre varié d'individus aux fins de la réalisation d'un inventaire complet d'arbres. Soixante-dix arbres ont été échantillonnés au hasard à partir d'un inventaire complet (100\%) d’arbres (7345 arbres) effectué précédemment sur le campus de l'université d'Auburn. Différentes équipes constituées d'un, de deux ou de trois personnes ont recueilli et enregistré des données à l'aide d'un appareil GPS qui notait l'heure du début et celle de la fin de la collecte de données pour chaque arbre. La durée moyenne de collecte pour chaque arbre a ensuite été calculée. Les équipes ont recueilli les données indépendamment et distinctement pour chacun des arbres afin qu'il n'y ait ni chevauchement, ni biais. Chaque arbre échantillonné a été visité par les trois types d'équipes à différents moments. La variation de la durée d'échantillonnage par arbre en considérant un DHP croissant a été déterminée en utilisant une analyse de régression et, subséquemment, des tests de rapport de vraisemblance F. Il n'y avait pas de différence statistique dans la période requise pour inventorier un arbre avec un DHP s'approchant du 0 (interception, temps fixe) pour une équipe de deux ou trois personnes, mais la durée requise (fixe) pour une personne seule était relativement plus grande (environ le double) indépendamment du DHP. La période de temps requise pour faire l'inventaire de chaque arbre augmentait avec l'accroissement du DHP; toutefois, le taux de variation était nettement moindre pour une équipe de trois personnes par rapport aux deux autres types déquipes. En se fondant sur ces résultats, le nombre et la dimension relative (DHP) des arbres à inventorier doivent être pris en considération lorsque vient le temps de déterminer la taille optimale des équipes de collecte.

Zusammenfassung. Die Bäume auf dem Campus der Auburn University (Auburn, Alabama, U.S.) wurden herangezogen, um die Effizienz von unterschiedlichen Mannschaftsstärken bei der Durchführung eines 100\%igen Baumkatasters zu testen. Siebzig Bäume wurden auf dem Campus der Auburn University aus einem vorangegangenen 100\%igen Baumkataster (7.345 Bäume) zufällig ausgewählt. Verschiedene Gruppen bestehend aus einem, zwei oder drei Individuen sammelten Daten und zeichneten sie auf mit einem GPS-Gerät, welches die Initiation und Vervollständigung der Datensammlung pro Baum zeitlich festhielt. Die durchschnittlich verbrachte Zeit pro Baum wurde anschließend kalkuliert. Die Gruppen besichtigten jedes Mal unterschiedliche Bäume, so dass es keine Überlappung oder Voreingenommenheit gab. Jeder begut- achtete Baum wurde von allen Gruppengrößen zu verschiedenen Zeiten besichtigt. Die Relation der zeitlichen Baumaufnahme pro Baum mit wachsendem dbh wurde unter Verwendung von Regressionsanalysen und nachfolgend mit Wahrscheinlichkeitsverhältnissen (F-Test) bestimmt. Es gab keine statistische Differenz in dem erforderlichen Zeitintervall zur Kontrolle eines Baumes, wenn der Baum dbh auf 0 (Abschnitt, fixierte Zeit) gestellt war, bei den Zweibis Drei-Menschengruppen, aber die Set-up-Zeit (fixiert) für den einzelnen Baumkontrolleur war signifikant größer (schätzungsweise $2 \mathrm{X}$ ) unabhängig von dbh. Der erforderliche Zeitintervall zur Untersuchung jedes Baumes wuchs mit ansteigendem dbh; dennoch war die Veränderungsrate bei einer Dreier-Gruppe deutlich niedriger als bei anderen Gruppenstärken. Basierend auf diesen Ergebnissen muss bei der Festlegung der optimalen Gruppenstärke die Anzahl und relative Größe ( $\mathrm{dbh}$ ) der zu begutachteten Bäume berücksichtigt werden.

Resumen. Árboles del campus de la Universidad de Auburn (Auburn, Alabama, EE.UU.) se utilizaron para probar la eficacia de los diferentes tamaños de equipos en la realización de un inventario de árboles al $100 \%$. Se muestrearon aleatoriamente setenta árboles a partir de un inventario al 100\% realizado anteriormente (7,345 árboles) en el campus de la Universidad de Auburn. Equipos diferentes, formados por uno, dos o tres individuos, colectaron y registraron los datos utilizando GPS que marcaba la fecha de la inicio y terminación de la recolección de datos para cada árbol. Luego se calculó el tiempo medio empleado por árbol. Los equipos visitaron árboles separados, de manera que no habría superposición o sesgo. Cada árbol muestreado recibió la visita de los tres tamaños de la tripulación en distintos momentos. La relación de tiempo de muestreo por árbol con el aumento del dap del árbol se determinó mediante análisis de regresión y posteriormente la verosimilitud con pruebas F. No hubo diferencia estadística en el intervalo requerido para inventariar un árbol con dap cerca de 0 (intercepción, hora fija) para una tripulación de dos y de tres personas, pero el tiempo para un equipo de una sola persona fue significativamente mayor (aprox. $2 \times$ ) independientemente del dap. El intervalo de tiempo que se tarda en inventariar cada árbol aumentó con el aumento dap; sin embargo, la tasa de variación fue significativamente menor para una tripulación de tres personas en comparación con los otros tamaños del equipo. En base a estos resultados, el número y tamaño relativo (dap) de los árboles que se inventariaron deben ser considerados al determinar el tamaño óptimo del equipo. 